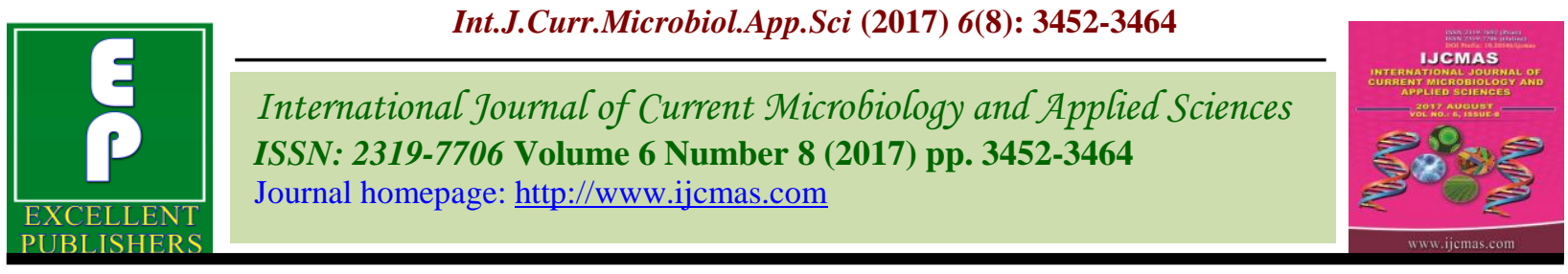

Original Research Article

https://doi.org/10.20546/ijcmas.2017.608.414

\title{
Development of an Index to Measure Women Empowerment through Dairy Cooperatives
}

\author{
L. Niketha ${ }^{1^{*}}$, Gopal Sankhala ${ }^{1}$, Kamta Prasad $^{2}$ and Sanjeev Kumar ${ }^{1}$ \\ ${ }^{1}$ National Dairy Research Institute, Karnal, Haryana, India \\ ${ }^{2}$ Indian Institute of Sugar Research, Lucknow, U.P., India \\ *Corresponding author
}

\begin{tabular}{|c|}
\hline Keywords \\
\hline $\begin{array}{l}\text { Index, } \\
\text { Empowerment, } \\
\text { Women, Dairying }\end{array}$ \\
\hline Article Info \\
\hline $\begin{array}{l}\text { Accepted: } \\
\text { 27 June } 2017 \\
\text { Available Online: } \\
10 \text { August } 2017\end{array}$ \\
\hline
\end{tabular}

This study assessed the empowerment of dairy women by developing an index by adopting a systematic procedure; seven dimensions under women empowerment were selected namely social, economic, psychological, cultural, political, legal and technological empowerment. The Normalised Rank Order Method was used for determining the scale values. These dimensions were ranked according to judges' perceived significance and proportions were calculated accordingly while determining the values for each, by Guilford table. To measure the empowerment, 71 indicators under each dimension were selected, due care was taken to include all relevant items. Out of 71 indicators under selected dimensions, 61 were retained for item analysis. Based on the rating of 30 judges, mean relevancy and overall mean relevancy scores were calculated. The statements having relevancy weightage $(\mathrm{RW})>0.70$ and Mean Relevancy Score (MRS) greater than the Grand Mean Relevancy Score i.e., 1.39 were considered for inclusion in Dairy Women Empowerment Index (DWEI) and finally 51 indicators were included.

\section{Introduction}

Women work two-thirds of the working hours, earn only ten per cent of the world's income, own less than one per cent of the world property and two-thirds out of the estimated 876 million adults worldwide who cannot read or write (FAO, 2010). Similarly, the contemporary scenario presents a gloomy depiction in India also. The sex ratio is declining decade by decade where in 1901 it was $972 / 1000$ males but at present it is 944/1000 male. Out of 128 countries, India ranked $115^{\text {th }}$ in the women empowerment (Anonymous ${ }^{\mathrm{a}}, 2012$ ) which indicates the low status of women in India. The unfair discrimination is more prevalent among rural women due to lack of access to resources and facilities. They remained as "invisible workers" and have not been given appropriate share in developmental agendas and programmes as less than 45 per cent of women in India have access to funds of their own, and only 15 per cent have a bank or savings account of their own (Kishor and Gupta, 2009). Two-third of the world 600 million poor livestock keepers are rural women (Thornton et al., 2003). In intensive Asian livestock systems, more than threequarters of livestock-related tasks were the responsibility of women (Niamer, 1994). There is a great variability across systems and 
socio-economic context; women generally play a major role in managing and caring for animals, even when they are not owners. As clearly pointed out by Flintan (2008) that woman participated in every aspects of livestock management in different pastoral systems around the world. Women are traditionally responsible for milking of animals, processing of milk and collecting dairy products (FAO, 2010). For equitable development of society and making the India a developed nation, better half of the society necessarily be empowered in true sense. Thus the empowerment of women has become one of the most important concerns not only at national level but also at the international level. Efforts by the government are on to ensure gender equality but government initiatives alone would not be sufficient to achieve this goal. Society must take initiative to create a climate in which there is no gender discrimination and women have full opportunities of self-decision making and participating in the social, political and economic life of the country with a sense of equality. In this direction dairy sector can play a major role as livestock are important in women's livelihoods and assets portfolios.

The government has initiated the empowerment of women through dairy farming by establishing exclusive women dairy cooperatives, however up to what extent these are being succeeded in achieving the goal is a question of investigation. Thus, studies on women empowerment through dairy cooperatives are the need of an hour. To conduct these type of study, measurement of empowerment is a tedious process for which limited number of measuring tools are available. Review provides information on the social and economic empowerment of women through different schemes and programme but they are unable to provide information on the other dimensions of empowerment like psychological, cultural, legal etc. So, necessary step was taken to develop an index with the inclusion of major dimensions of empowerment and to check the level of empowerment of women involved in dairying.

\section{Materials and Methods}

This section usually deals with procedural steps required to accomplish the objectives laid down for the investigation. An attempt was made to explain the various methods and procedures followed to devise the Dairy Women Empowerment Index (DWEI) under the following sub-heads:

\section{Formulation of construct}

It is imperative to operationalise the different concept for ease of measurement. In other words construct to be formulated in light of the scientific study. A construct is a concept. It has the added meaning, however, of having been deliberately and consciously invented or adopted for a special scientific purpose (Kerlinger, 2012). Different constructs devised/adopted for present purpose are as under:

\section{Dairy Women Empowerment}

It was operationally defined as the process that facilitates the women to realize their identity, capacity, strengths, decision-making and power through Women Dairy Cooperatives.

\section{Dairy Women Empowerment Index}

A Dairy Women Empowerment Index (DWEI) as an aggregation of sets of variables for the purpose of meaningfully condensing large amounts of information related to empowerment of women through dairy cooperatives. It was developed to evaluate the role of Women Dairy Cooperatives (WDC) in 
empowering the women members of the society.

\section{Development of Dairy Women Empowerment Index (DWEI)}

Kerlinger (1983) defined an Index as "number that is composite of two or more other numbers". A composite index can be defined as an aggregation of sets of variables for the purpose of meaningfully condensing large amounts of information.

Dairy based women empowerment index is developed as under:

\section{Selection of Dimensions}

The empowerment has multidimensional aspects. A meticulous review of literature and discussion with the experts in relevant field played an important role in the identification of empowerment's dimensions. Broadly, these dimensions were grouped into seven categories: (i) Social empowerment (ii) Economic empowerment (iii) Psychological empowerment (iv) Cultural empowerment (v) Political empowerment (vi) Legal empowerment (vii) Technological empowerment. The identified dimensions of dairy women empowerment were operationalised as :

\section{Social empowerment}

It was operationally defined as the social status of dairy women members with respect to decision making in family as well as community, freedom of mobility and her involvement in various social activities.

\section{Economic empowerment}

It is operationally defined as the control over the resources, access to financial sources and accumulation of the financial capital.

\section{Psychological empowerment}

It was operationally defined as the mental stability with respect to the self-confidence, self-reliance, courage, self-image in the social system.

\section{Cultural empowerment}

It was operationally defined as her involvement in different cultural activities carried out by WDCs.

\section{Political empowerment}

It was operationally defined as awareness about the political institutions, accessing the political power, freedom and her own decision in voting and contesting for the election.

\section{Legal empowerment}

It was operationally defined as the awareness and knowledge about the legislation related to women, child and society.

\section{Technological empowerment}

It was operationally defined as the awareness, accessibility and application of scientific knowledge in the field of dairy enterprise.

\section{Determination of Scale Values}

It has been decided to give specific weights (Scale Values) to each dimension of the DWEI based on their perceived significance.

The Normalised Rank Order Method suggested by Guilford (1954) was used for determining the scale values.

The method has got a unique advantage that it can be used with any number of variables and does not require a large number of judges. 


\section{Judges' rating}

As per the method, seven dimensions of DWEI were ranked by the judges according to their perceived significance in determining the status of empowerment of dairy women members. Ranking was obtained from judges who are the experts in the field of Social Science, Extension Education and Rural Development. Pro forma containing dimensions of DWEI was sent by post, through e-mail and also handed over personally to the total 40 judges for ranking (1 to 7) dimensions according to their relevance. Out of 40 judges, 35 judges had returned the same set of indicators after duly recording their judgements in a stipulated span of 2 months. Out of 35 responses, 5 responses were found unsuitable for item analysis and eliminated after careful examination of responses. The remaining 30 responses were considered for item analysis. The rankings given by all 30 judges were summarised and presented in table 1 .

\section{Calculation of proportions}

The proportions were worked out for the ranks assigned by all the judges. The formula is $\mathrm{p}=\frac{(R i-0.5) 100}{n}$, where $\mathrm{R}_{\mathrm{i}}$ stands for the rank value of the dimension $\mathrm{i}$ in the reverse order as 7 to 1 and $n$ indicates the number of dimensions ranked by the judges. Here we needed the middle area of the dimensions ranked. The $p$ is the centile value which indicated the area of the dimensions in the normal distribution. The $p$ values were worked out for all the ranks shown in table 1. Thus, $p$ values for the ranks ranged from the lowest 7.14 to 92.86 .

\section{Determining the $\mathrm{C}$ values}

The correct rank order (1 to 7) is given in the column order $R_{i}$ in table 1 . The second column $R_{i}$ in table 1 is the reverse rank order
(7 to 1). The $\mathrm{C}$ values were determined for each rank from the table - M (Guilford 1954, p.557). These values can be traced by putting the finger on the column extreme left of the Table-M, on the number which indicates the number of stimuli used in the experiment. In the case of this experiment the numbers of dimensions were 7 thus the number of stimuli to be ranked were 7 . While moving the finger from this number 7 towards right, stop at the number which indicates the rank $\left(\mathrm{r}_{\mathrm{i}}, 7\right)$. Above the rank number you can find the respective $\mathrm{C}$ value 4 for the rank 7 and this can be entered in table 1 under the letter $\mathrm{C}$. the $\mathrm{C}$ values are from 1 to 9 only. The same procedure may be adapted in finding out the $\mathrm{C}$ values for all the ranks $\left(\mathrm{r}_{\mathrm{i}}\right)$ from table-M.

\section{Calculation of $\sum\left(f_{j} \mathbf{C}\right)$ value for all the dimensions}

The next step is to find out the $\sum\left(\mathrm{f}_{\mathrm{ji}} \mathrm{C}\right)$ value for all the dimensions. This value for every dimension was obtained by multiplying the frequencies found in the columns of the respective dimension by the $\mathrm{C}$ values of the rank $\left(r_{i}\right)$, and summing up the products for each dimension and entering the same in the row against $\sum\left(\mathrm{f}_{\mathrm{ji}} \mathrm{C}\right)$. The mean of the total frequencies, that is for the whole data of the matrix was $5.86\left(\frac{1230}{210}=5.86\right)$ and the mean of the $C$ values was $5.85\left(\frac{41}{7}=5.85\right)$.

\section{Calculation of scale values of dimensions}

The $\sum\left(\mathrm{f}_{\mathrm{ji}} \mathrm{C}\right)$ values for each dimension was divided by the total number of judges 30 , which resulted in obtaining the $M_{c}=R_{j}$. The treatment of data can be stopped at this stage and the $\mathrm{M}_{\mathrm{c}}$ values can be accepted and treated as the scale values. The total value was 41 which was also the total sum of the $C$ values, and the mean of the $M_{c}$ or $R_{j}$ or $R_{c}$ values was 5.86. The standard deviation and standard error of the $\mathrm{M}_{\mathrm{c}}$ values was 0.92 and 0.17 , respectively. The obtained scale values $\left(\mathrm{R}_{\mathrm{c}}\right)$ 
were shown in table 1 against row $\mathrm{M}_{\mathrm{c}}$ or $\mathrm{R}_{\mathrm{j}}$ or $\mathrm{R}_{\mathrm{c}}$.

\section{Selection of indicators}

Selection of effective indicators is the key to the overall success of any measuring instruments. To measure the empowerment, indicators under each dimension were selected after preliminary survey of the study area, literature scan, consultation of the experts such as scientists, officials of the related departments and personnel from NGOs working in the area. Due care was taken to include all relevant items. The procedure involved could ensure the efficiency of the instrument to measure the dairy women empowerment by ascertaining content validity. The following steps were followed for selecting relevant indicators under each dimension of DWEI.

\section{Collection and editing of indicators}

By referring the available literature on relevant subject, a total 71 indicators were collected covering the almost entire universe or content. The researchers, farmers and extension experts were also consulted for selecting indicators. The indicators were edited as per the 14 informal criteria suggested by Edwards (1957) and as an outcome 10 indicators were eliminated. Finally, 61 indicators were retained after editing and considered for judge ${ }^{\mathrm{s}}$ rating.

\section{Response to indicators}

The pro forma containing 61 indicators on three point continuums i.e. Most Relevant, Relevant and Not Relevant with respective scores of 3, 2 and 1 was sent by post, through e-mail and also handed over personally to the total 40 judges. These judges were experts in the field of extension education, social science and rural development, etc. The judges were requested to indicate their response by their tick mark in suitable column in front of each item. Also the judges were requested to make necessary modifications and additions or deletions, if they desired so. Out of 40 judges 35 judges had returned the same set of items after duly recording their judgements in a stipulated span of one month. Out of 35 responses, 5 responses were found unsuitable for item analysis and eliminated after careful examination of responses. The remaining 30 responses were considered for the item analysis.

\section{Relevancy test}

Item analysis is an important step while constructing valid and reliable index. It is possible that the all the items collected may not be relevant equally in measuring the status of empowerment. Hence, these items were subjected to scrutiny and their subsequent screening for inclusion in the final index. The judges were asked to indicate degree of relevancy on each items in three point continuums 'Most Relevant, Relevant and Not Relevant' with respective scores of 3, 2 and 1 . The relevancy weightage (RW) and mean relevancy score (MRS) were worked out for all the selected indicators individually as well as grand mean relevancy score (GMRS) including all the indicators was calculated by using the following formula:

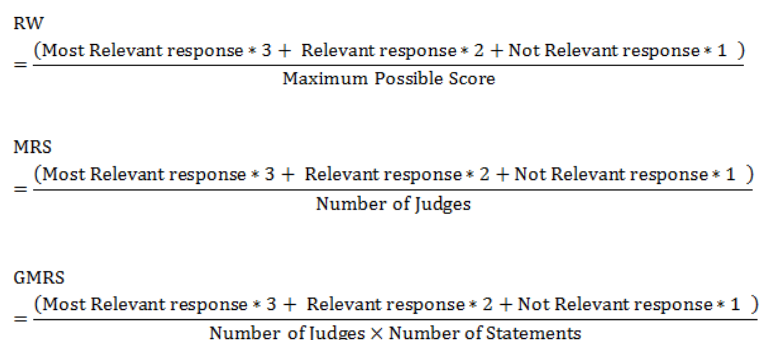

By these two criteria the statements having relevancy weightage (RW) $>0.70$ and Mean Relevancy Score (MRS) greater than the Grand Mean Relevancy Score i.e., 1.39 were 
considered for inclusion in Dairy Women Empowerment Index (DWEI) and finally 51 statements were included. The finally selected dimensions of DWEI and statements under these with respective relevancy weightage as well as mean relevancy scores are given in table 2 .

\section{Computation of the composite index}

Each dimension of DWEI consists of number of statements and hence, their range of total scores was different. Therefore, the total score of each dimension was converted into unit score by using simple range and variance as given below,

$\mathrm{Uij}_{i j}=\frac{\mathrm{Yij}-\mathrm{Min} \mathrm{Yij}_{\mathrm{j}}}{\operatorname{Max} \mathrm{Yj}-\operatorname{Min} \mathrm{Y}_{\mathrm{j}}}$

Where,

$\mathrm{U}_{\mathrm{ij}}=$ Unit score of the $\mathrm{i}^{\text {th }}$ respondents on $\mathrm{j}^{\text {th }}$ dimension

$\mathrm{Y}_{\mathrm{ij}}=$ Value of the $\mathrm{i}^{\text {th }}$ respondent on the $\mathrm{j}^{\text {th }}$ dimension

Max $Y_{j}=$ Maximum score on the $j^{\text {th }}$ dimension

Min $\mathrm{Y}_{\mathrm{j}}=$ Minimum score on the $\mathrm{j}^{\text {th }}$ dimension

Thus, the score of each dimension range from 0 to 1 i.e. when Yij is minimum, the score is 0 and when Yij is maximum the score is 1. Then the unit scores of each respondent was multiplied by respective scale value of each dimension and summed up. Thus, the obtained score was divided by the sum of scale values in order to get the DWEI for each respondent.

$D W E I i=\frac{\sum \mathrm{Uij} * \mathrm{Sj}}{\text { Sum of scale values }}$

Where,
DWEI $_{\mathrm{i}}=$ Dairy Women Empowerment Index of $i^{\text {th }}$ respondent

$\mathrm{U}_{\mathrm{ij}}=$ Unit score of the ith respondent on $\mathrm{jth}$ component

$\mathrm{Sj}=$ Scale value of the $\mathrm{jth}$ component

$\sum=\operatorname{Sum}$

The status of respondents' empowerment was calculated based on the total index score of all the indicators.

The classification of respondents into the categories of low, medium and high was based on the cumulative square root frequency method.

\section{Standardisation of index}

The validity was ascertained for standardisation of the index. It is the property that ensures the obtained scores as valid, if and only if it measure what it is supposed to measure. An index is said to be valid if it stands for one's reasoning. The validity was measured by content validity. The content validity of the index was tested by expert's judgement.

The content validity is the representative or sampling adequacy of the content, the substance, the matter and the topics of a measuring instrument. This method was used in the present index to determine the content validity of the index. The content of the index was thoroughly covered with literature scan and expert opinions. The indicators having relevancy score of $>0.70$ were retained.

As it indicates that more than 70 per cent of judges rated the statement as relevant which indicates that statement is unambiguous. This indicated validity of the index content. As the 
scale values, relevancy weightages and mean relevancy scores of all the dimensions and indicators had discriminating values, it seemed reasonable to accept the index as valid measure of the desired dimension.

\section{Results and Discussion}

Final index containing 51 statement in the form of interview schedule was used to collect data on empowerment and the results are discussed as below:

\section{Categories according to overall} empowerment of respondents

Table 3 depicts that amongst respondents 43.33 per cent of them were in category of medium empowerment level followed by 36.25 per cent of the respondents in low category and less than one-fourth (20.42\%) of them in high category of overall empowerment. The results are in line with the findings of Kumari (2008) and Pandey (2005).

It implies that Women Dairy Cooperatives (WDCs) have started showing their positive impact on empowerment of women at the moderate level.

Kant (2001) observed that the process of women's empowerment is multidimensional as it enables them to realize their full potential and empower them in various spheres of life.

The frequencies of ranks as given by judges for seven dimensions DWEI by using Normalised Rank Order method suggested by Guilford (1954)

Ranking for seven different dimensions of DWEI were ranked by judges (experts involved in the field of Social Science, Extension Education and Rural Developments) according to their perceived significance in determining the status of empowerment of dairy women members.

From the table 4 , it could be revealed that according to experts the first and foremost importance for empowering women is economic empowerment which paves the way for other different dimensions of empowerment where they ranked social empowerment as second, psychological as third, legal as fourth, fifth as cultural followed by technological \& political as sixth and seventh, respectively.

It could be enunciated that according to experts, women should be financially sound enough which acts as a core for empowerment leading her to decision making abilities in family as well as community while the mobility in society brew her mental stability with respect to the self-confidence, selfreliance and making her aware about the legislations in the social system.

These factors encourage her to take part in cultural activities, accessibility to technology, awareness about political institutions and also accessing towards the political power.

Ranks as given by respondents for seven dimensions of empowerment by using weighted mean score (WMS)

It was observed from table 5 that according to dairy women strongest component of empowerment which they achieved through women dairy cooperative activity was psychological empowerment as it obtained I rank followed by social empowerment (Ranked II), economic empowerment (Ranked III), legal empowerment (Ranked IV), cultural empowerment (Ranked V), technological empowerment (Ranked VI) and political empowerment (Ranked VIII). 
Table.1 The frequencies of ranks as given by judges, proportions $(p), \mathrm{C}$ values and $\mathrm{R}_{\mathrm{c}}$ values for seven dimensions DWEI by using Normalised Rank Order method suggested by Guilford (1954)

\begin{tabular}{|c|c|c|c|c|c|c|c|c|c|c|c|}
\hline \multirow[t]{2}{*}{$\mathbf{r}_{\mathbf{i}}$} & \multirow[t]{2}{*}{$\mathbf{R}_{\mathbf{i}}$} & \multicolumn{7}{|c|}{ Seven Dimensions of Dairy Women Empowerment Index } & \multirow[t]{2}{*}{$\sum$} & \multirow[t]{2}{*}{$\mathbf{p}$} & \multirow[t]{2}{*}{$\mathbf{C}$} \\
\hline & & $\begin{array}{l}\text { Social } \\
\text { Empowermen } \\
\mathbf{t}\end{array}$ & $\begin{array}{l}\text { Cultural } \\
\text { Empowermen } \\
\mathbf{t}\end{array}$ & $\begin{array}{c}\text { Psychological } \\
\text { Empowermen } \\
\text { t }\end{array}$ & $\begin{array}{l}\text { Economic } \\
\text { Empowerme } \\
\text { nt }\end{array}$ & $\begin{array}{c}\text { Political } \\
\text { Empowerme } \\
\text { nt }\end{array}$ & $\begin{array}{c}\text { Technologica } \\
\text { I } \\
\text { Empowerme } \\
\text { nt }\end{array}$ & $\begin{array}{l}\text { Legal } \\
\text { Empowerme } \\
\text { nt }\end{array}$ & & & \\
\hline 1 & 7 & 11 & 0 & 7 & 12 & 0 & 0 & 0 & 30 & 92.86 & 8 \\
\hline 2 & 6 & 8 & 3 & 6 & 7 & 2 & 0 & 4 & 30 & 78.57 & 7 \\
\hline 3 & 5 & 7 & 5 & 3 & 6 & 2 & 3 & 4 & 30 & 64.29 & 6 \\
\hline 4 & 4 & 3 & 3 & 5 & 4 & 2 & 3 & 10 & 30 & 50.00 & 6 \\
\hline 5 & 3 & 1 & 6 & 7 & 0 & 5 & 4 & 7 & 30 & 35.71 & 5 \\
\hline 6 & 2 & 0 & 1 & 2 & 1 & 10 & 14 & 2 & 30 & 21.43 & 5 \\
\hline 7 & 1 & 0 & 12 & 0 & 0 & 9 & 6 & 3 & 30 & 7.14 & 4 \\
\hline & & 30 & 30 & 30 & 30 & 30 & 30 & 30 & 210 & 350 & 41 \\
\hline & & 209 & 152 & 191 & 210 & 149 & 150 & 169 & 1230 & \multirow{2}{*}{\multicolumn{2}{|c|}{$\begin{array}{l}\text { Mean }=5.86 \\
\mathrm{SD}=0.92\end{array}$}} \\
\hline $\begin{array}{r}\text { Mc } \\
\mathbf{o} \\
\left(\sum \mathbf{f j}\right)\end{array}$ & & 6.97 & 5.07 & 6.37 & 7.00 & 4.97 & 5.00 & 5.57 & 41 & & \\
\hline \multicolumn{7}{|c|}{$\begin{array}{l}\mathrm{r}_{\mathrm{i}}=\text { Correct Rank order, } \mathrm{R}_{\mathrm{i}}=\text { Reverse rank order, } \sum=\text { Sum, } p=\text { Proportion, } \\
\mathrm{C}=\mathrm{C} \text { values of respective ranks, } \mathrm{M}_{\mathrm{c}}=\text { Mean Value, } \mathrm{R}_{\mathrm{j}}=\text { Response value, } \\
\mathrm{R}_{\mathrm{c}}=\text { Scale Value, } \sigma_{=} \text {Standard Deviation }\end{array}$} & \multicolumn{5}{|c|}{ Standard Error for $\mathrm{M}_{\mathrm{C}}=\frac{\sigma}{\sqrt{N}}=\frac{0.89}{\sqrt{30}}=\mathbf{0 . 1 7}$} \\
\hline
\end{tabular}


Table.2 Relevancy weightage and mean relevancy scores of different items

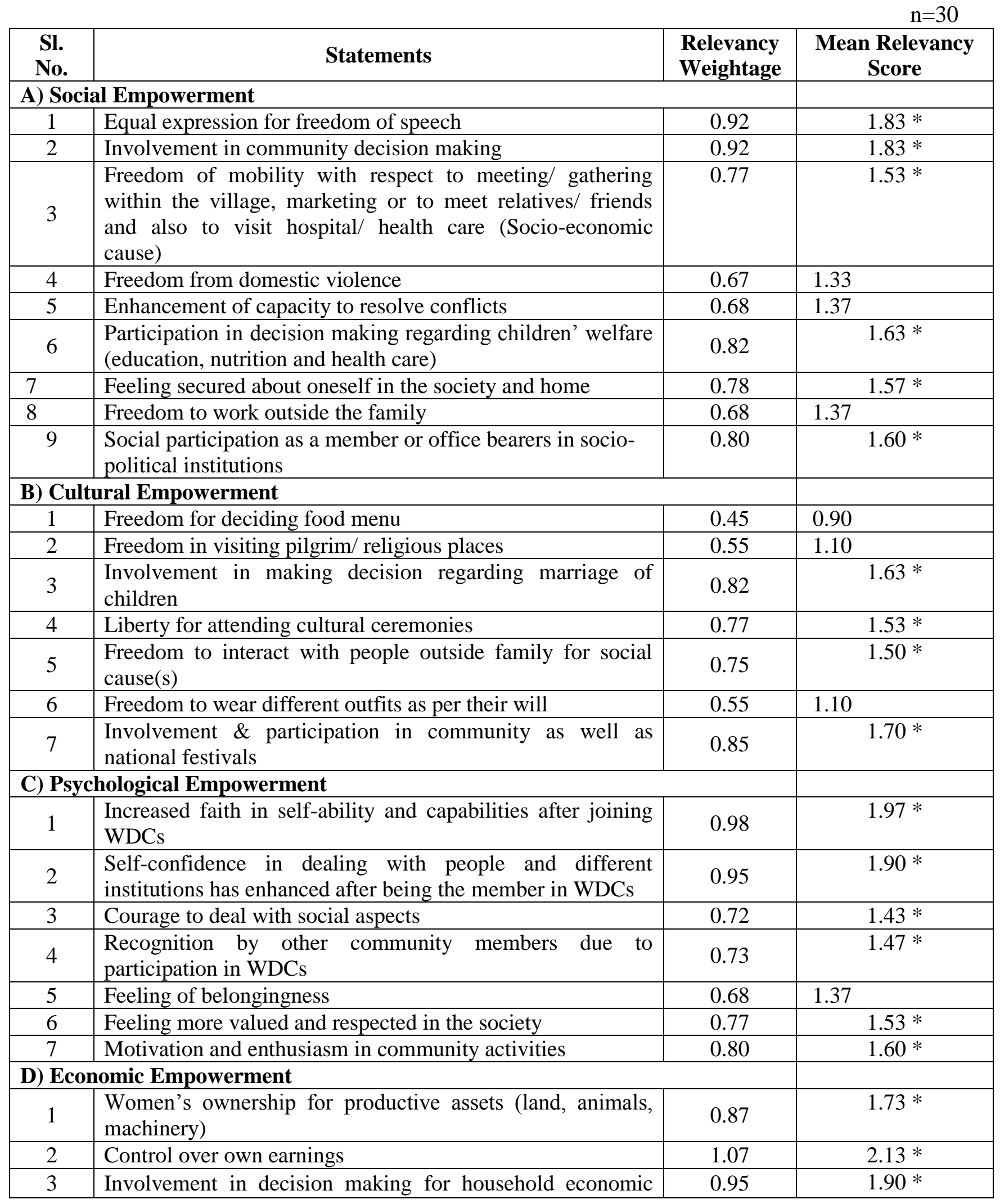




\begin{tabular}{|c|c|c|c|}
\hline & activities & & \\
\hline 4 & Control on expenditure and savings of households & 0.82 & $1.63 *$ \\
\hline 5 & $\begin{array}{l}\text { After being a member of Women Dairy Cooperative } \\
\text { Society, economic status has been improved }\end{array}$ & 0.72 & $1.43 *$ \\
\hline 6 & Reduced dependency on money lenders & 0.57 & 1.13 \\
\hline 7 & Increase in family assets due to participation in WDCs & 0.75 & $1.50 *$ \\
\hline 8 & Opportunity to capitalise dairy ventures & 0.75 & $1.50 *$ \\
\hline 9 & Operating personal accounts in bank & 0.85 & $1.70 *$ \\
\hline 10 & Decision making about taking loan for livelihood & 0.78 & $1.57 *$ \\
\hline \multicolumn{4}{|c|}{ E) Political Empowerment } \\
\hline 1 & Awareness about political institutions & 0.80 & $1.60 *$ \\
\hline 2 & Holding a political position & 0.68 & 1.37 \\
\hline 3 & Participation in electoral process & 0.85 & $1.70 *$ \\
\hline 4 & Contested in election of Gram Panchayat /other local bodies & 0.77 & $1.53 *$ \\
\hline 5 & Solving women's problem through political means & 0.75 & $1.50 *$ \\
\hline 6 & Access and freedom to participate in political activities & 0.78 & $1.57 *$ \\
\hline \multicolumn{4}{|c|}{ F) Technological Empowerment } \\
\hline 1 & Decision to choose and use the technology & 0.85 & $1.70 *$ \\
\hline 2 & Freedom to consult the experts & 0.78 & $1.57 *$ \\
\hline 3 & Awareness about scientific feeding for animals & 0.83 & $1.67 *$ \\
\hline 4 & $\begin{array}{l}\text { Access to communication gadgets i.e. mobile, computers, } \\
\text { internet, etc. }\end{array}$ & 0.78 & $1.57 *$ \\
\hline 5 & Awareness about clean milk production practices & 0.85 & $1.70 *$ \\
\hline 6 & Awareness about machine milking & 0.70 & $1.40 *$ \\
\hline 7 & Use of artificial insemination for animals & 0.77 & $1.53 *$ \\
\hline 8 & Timely vaccination $\&$ de-worming of animals & 0.78 & $1.57 *$ \\
\hline 9 & $\begin{array}{l}\text { Awareness about symptom and prevention measures of } \\
\text { diseases }\end{array}$ & 0.83 & $1.67 *$ \\
\hline 10 & Knowledge about SNF \& fat estimation test & 0.72 & $1.43 *$ \\
\hline 11 & Orientation of cattle shed & 0.57 & 1.13 \\
\hline 12 & Skill acquisition in handling improved equipments & 0.85 & $1.70 *$ \\
\hline 13 & Awareness about improved fodder production practices & 0.77 & $1.53 *$ \\
\hline \multicolumn{4}{|c|}{ G) Legal Empowerment } \\
\hline 1 & Knowledge about the structure of law and its importance & 0.77 & $1.53 *$ \\
\hline 2 & Free to consult the lawyers and the way to approach them & 0.72 & $1.43 *$ \\
\hline 3 & Going to mahila courts/ family courts in time of need & 0.77 & $1.53 *$ \\
\hline 4 & Approach to police station when they have a problem & 0.72 & $1.43 *$ \\
\hline 5 & Free to discuss with the law enforcement bodies & 0.70 & $1.40 *$ \\
\hline 6 & $\begin{array}{l}\text { Awareness about protection of women under Domestic } \\
\text { Violence Act }\end{array}$ & 0.78 & $1.57 *$ \\
\hline 7 & Awareness about Right to Information Act & 0.78 & $1.57 *$ \\
\hline 8 & Awareness about women helpline & 0.90 & $1.80 *$ \\
\hline 9 & $\begin{array}{l}\text { Attending training programmes on legal laws regularly when } \\
\text { arranged by co-operatives }\end{array}$ & 0.75 & $1.50 *$ \\
\hline \multicolumn{2}{|c|}{ Grand Mean Relevancy Score } & \multicolumn{2}{|r|}{1.39} \\
\hline
\end{tabular}

(* - Selected items for the Index) 
Table.3 Categories according to overall empowerment of respondents

\begin{tabular}{|l|c|c|}
\hline Overall Empowerment category & Freequency & Percentage \\
\hline Low (upto 0.58) & 87 & 36.25 \\
\hline Medium (0.59-0.68) & 104 & 43.33 \\
\hline High (above 0.68) & 49 & 20.42 \\
\hline
\end{tabular}

Table.4 The frequencies of ranks as given by judges for seven dimensions DWEI by using normalised rank order method suggested by Guilford (1954)

\begin{tabular}{|l|l|c|c|}
\hline Sl. No. & $\begin{array}{l}\text { Seven Dimensions of Dairy } \\
\text { Women Empowerment Index }\end{array}$ & Calculated Mc or Rj & Rank \\
\hline 1. & Social Empowerment & 6.97 & II \\
\hline 2. & Cultural Empowerment & 5.07 & V \\
\hline 3. & Psychological Empowerment & 6.37 & III \\
\hline 4. & Economic Empowerment & 7.00 & I \\
\hline 5. & Political Empowerment & 4.97 & VII \\
\hline 6. & Technological Empowerment & 5.00 & VI \\
\hline 7. & Legal Empowerment & 5.57 & IV \\
\hline
\end{tabular}

(Note: $\mathrm{M}_{\mathrm{c}}=$ Mean Value, $\mathrm{R}_{\mathrm{j}}=$ Response value)

Table.5 Ranks as given by respondents for seven dimensions of empowerment by using Weighted Mean Score (WMS)

\begin{tabular}{|l|l|c|c|}
\hline Sl. No. & $\begin{array}{l}\text { Seven Dimensions of Dairy } \\
\text { Women Empowerment Index }\end{array}$ & WMS & Rank \\
\hline 1. & Social Empowerment & 1.47 & II \\
\hline 2. & Cultural Empowerment & 1.23 & V \\
\hline 3. & Psychological Empowerment & 1.48 & I \\
\hline 4. & Economic Empowerment & 1.39 & III \\
\hline 5. & Political Empowerment & 0.99 & VII \\
\hline 6. & Technological Empowerment & 1.18 & VI \\
\hline 7. & Legal Empowerment & 1.27 & IV \\
\hline
\end{tabular}

Table.6 Comparison of the ranks given by the judges and the ranks obtained by the respondents to each dimension of the empowerment

\begin{tabular}{|l|l|l|l|}
\hline Sl. No. & $\begin{array}{l}\text { Seven Dimensions of Dairy Women } \\
\text { Empowerment Index }\end{array}$ & $\begin{array}{l}\text { Ranks given } \\
\text { by judges }\end{array}$ & $\begin{array}{l}\text { Ranks obtained by } \\
\text { respondents }\end{array}$ \\
\hline 1. & Social Empowerment & II & II \\
\hline 2. & Cultural Empowerment & V & V \\
\hline 3. & Psychological Empowerment & III & III \\
\hline 4. & Economic Empowerment & I & VII \\
\hline 5. & Political Empowerment & VII & VI \\
\hline 6. & Technological Empowerment & VI & IV \\
\hline 7. & Legal Empowerment & IV & \\
\hline
\end{tabular}


Comparison of the ranks given by the judges and the ranks obtained by the respondents to each dimension of the empowerment

From the table 6, we can reveal the comparison of ranks given by the experts and the respondents which executes the difference between judges and respondents opinion because as judges feel economic dimension is most important than any other types of dimensions but in contrast dairy women opined that psychological empowerment was crucial than any other dimensions however the judges had ranked third for it while dairy women gave economic dimension the third place.

Amid there was synchronization of opinion in both judges and respondents in the dimensions like legal, technological, cultural and political (fourth, fifth, sixth and seventh respectively).

By the above results it can be concluded that psychological empowerment (self-confidence, belief in self-abilities) is the first and foremost basic need for the women to be empowered. If she is mentally strong, it leads to empowerment in other dimensions also. Once she is psychologically empowered, it helps her to take the responsibilities and deal with different institutions making her socially empowered, then economically empowered due to fiscal activities. The results are similar with findings of Pandey (2005). However, Anuradha (2004) reported that socioeconomic empowerment of rural women obtained the highest mean score. Furthermore, Dhaiya (2001) also reported that the social impact of SHGs was deep in empowering women folk, educational development of children and emancipation from social evils like drunkenness by male household members. However, comparatively dairy women members were less technologically empowered as dimension itself is complex, which requires considerable efforts on regular basis for comparatively longer duration. However, WDCs are in their infancy. So, required impulse could not be reached for fullest technological upliftment. Further, other dimensions of empowerment seem to be less complex. Therefore, empowerment was found to be more.

\section{References}

Anonymous, 2010-11. Report of Food and Agriculture Organization (FAO) on women in agriculture: Closing the gender gap for development.

Anonymous, 2012a. Department of Animal Husbandry and Dairying, Ministry of Agriculture, New Delhi.

Anuradha, 2004. Empowerment of rural women under SWA - Shakthi project through self-help groups. M.Sc. Thesis (Unpub.), CCS Haryana Agriculture University, Hisar.

Breslin, G., 2011. Collins English Dictionary. ISBN 0007437862，9780007437863, HarperCollins: 1- 1899.

Dhaiya, P. S., Pandey, N. K. \& Karol, A. 2001. Socio-economic evaluation of self-help groups in Solan district of Himachal Pradesh: Impact, issues and policy implications. Indian Journal of Agricultural Economics, 56 (3): 486487.

Edwards, A.L., 1957. Techniques of Attitude Scale Construction. Vakils, Feffer and Simons Private Ltd., Bombay Guilford JP (1954) Psychometric Methods

Flintan, F., 2008. Women's Empowerment in Pastoral Socities. World Initiative for Sustainable Pastoralism, GEF, UNDP \& International Union for Conservation of Nature: 1-125.

Guilford, J. P., 1954. Psychological methods. Tata McGraw Hill Publishing Co. Ltd.

Kant, J., 2001. Catching up with education. 
Yojana, August, New Delhi.

Kerlinger, F.N., 2012. Foundations of Behavioral Research (Second Ed.). Fourteenth reprint, 2012. Surjeet Pub., Delhi, India, pp1-741

Kishor, S., and Gupta, K. 2009. Gender equality and women's empowerment in India. National Family Health Survey India. Ministry of Health and Family Welfare, Government of India, New Delhi.

Kumari, P., 2008. Gender analysis of dairy cooperatives in Harayana. Ph.D. Thesis (Unpub.), National Dairy Research Institute, Karnal, Haryana.
Niamer, F. M., 1994. Women livestock managers in the third World: focus on technical issues related to gender roles in livestock production. Staff Working Paper 18, IFAD, Rome.

Pandey, R., 2005. Empowerment of women through women dairy cooperatives. Ph.D. Thesis (Unpub.), National Dairy Research Institute, Karnal, Haryana.

Thornton, P. K., Kruska, R. L., Henninger, N., Kristjanson, P. M., Reid, R. S. and Robinson, T. P. 2003. Locating poor livestock keepers at the global level for research and development targeting. Land use Policy, 20 (4): 311-322.

\section{How to cite this article:}

Niketha, L., Gopal Sankhala, Kamta Prasad and Sanjeev Kumar. 2017. Development of an Index to Measure Women Empowerment through Dairy Cooperatives. Int.J.Curr.Microbiol.App.Sci. 6(8): 3452-3464. doi: https://doi.org/10.20546/ijcmas.2017.608.414 